\section{Author Index, Volume 78, 2002}

Adamowicz, W.L., T.S. Veeman, G. Binsted, B. Macnab, D. Korber and A. Coyne - The Sustainable Forest Management Network:

Maintaining scientific excellence and relevance in a changing world 112

Amiro, B.D., M.D. Flannigan, B.J. Stocks and B.M. Wotton -

Perspectives on carbon emissions from Canadian forest fires

Anderson, F. - See Schaan, S.

Anderson, P.D., J.C. Zasada, G.W. Erickson and Z.A. Zasada -

Thinning in mature eastern white pine: 43-year case study

Apps, M. - See Kurz, W.A.

Apps, M. - See Lemprière, T.C.

Apsey, M. - Science and technology and innovation: Essential keys

to sustainable forests nationwide

Baker, J.A., D. DeYoe, D. McKee and M.L. Willick - Performance

management and forest science in Ontario

Banfield, E. - See Kurz, W.A

Barkley, B - See Holmes, E.

Beaton, K. P. - See MacLean, D.A.

Beckley, T., J. Parkins and R. Stedman - Indicators of forest-

dependent community sustainability: The evolution of research

Beese, W.J. - See Mitchell, S. J.

Benskin, H.J. and A. Vyse, - British Columbia Forest Service's Science

Program: Science to support sustainability

Besseau, P., K. Dansou and F. Johnson - The International

Model Forest Network (IMFN): Elements of success

Betts, M. and J. Loo - A comparison of pre-European settlement

forest characterization methodologies

Beyeler, J. - Research on forestry practices to sustain the Acadian

Forest in Nova Scotia

Binsted, G. - See Adamowicz, W.L.

Bisson, D. - See Lemprière, T.C.

Bogdanski, B. - See Lemprière, T.C

Bourgeois, W.W. - Science and technology (S \& T) opportunity

for a small forest company

Bowne-Clayton, S. - See Martin, P.J.

Budd, M.G. - See MacLean, D.A

Bussler, O. - See Lemprière, T.C.

Calogeropoulos, C. - See Greene, D.F.

Chouinard, O. and J. Perron - Learning about community

capacity in the Fundy Model Forest

Ciesla, W.M. - Observations on the life history and habits of a

tropical sawfly, Sericoceros mexicanus (Kirby), (Hymenoptera:

Argidae) on Roatán Island Honduras

Cieszewski, C.J. and G.D. Nigh - A dynamic equation for a

published Sitka spruce site-dependent height-age model

Cinq-Mars, J. and E. Wiken - Using science, technology and

innovation in support of conserving Canada's ecosystems and

habitats

Coates, K.D. - See Greene, D.F.

Cohen, D.H. and R.A. Kozak - Research and technology:

Market-driven innovation in the twenty-first century

Comeau, R. - See Gauthier, J.

Cormier, D. - See Greene, D.F.

Côté, M.-A. - The innovation system in Quebec's forest sector

Coyne, A. - See Adamowicz, W.L.

Dangerfield, J.A. - See de la Roche, I.A.

Dansou, K. - See Besseau, P.

David, A.J. - See Gilmore, D.W.

de la Roche, I.A. and J.A. Dangerfield - The power of partnerships in research and development

DeGiacomo, J.A. - Experiential learning in higher education

D'Eon, R. - Forest fragmentation and forest management: A plea for empirical data

DeYoe, D. - See Baker, J.A

Dolter, S. - See Moores, L.

Dorion, F. - See Yamasaki, S.H.

Doucet, R. - See Greene, D.F.

Duchesne, L.C. and S. Wetzel - Managing timber and non-timber forest product resources in Canada's forests: Needs for integration and research

Duff, S.J.B. - See Orban, J.L.

Duinker, P.N. - See Saunders, K.C

Egawa, T. - Newsprint market in Japan - Next to none in its peculiarity
Ehnes, J. and V. Keenan - Implementing wildfire-based timber harvest guidelines in southeastern Manitoba

Erdle, T. and J. Pollard, J. - Are plantations changing the tree species composition of New Brunswick's forest?

Erickson, G.W. - See Anderson, P.D.

Euler, D. - See Leadbitter, P

Farnden, C. and L. Herring - Severely repressed lodgepole pine responds to thinning and fertilization: 19-year results

Flannigan, M.D. - See Amiro, B.D.

Franklin, S.E., M.B. Lavigne, M.A. Wulder and G.B. Stenhouse -

Change detection and landscape structure mapping using remote

sensing

Franklin, S.E., M.J. Hansen and G.B. Stenhouse - Quantifying

landscape structure with vegetation inventory maps and remote sensing

Gantotti, B. - Extending forestry's R \& D investments through

SR \& ED Program incentives

Gautam, K.H. and T. Watanabe - Silviculture for non-timber forest product management: challenges and opportunities for sustainable

forest management

Gauthier, J., C. Parsons and R. Comeau - Are forest practitioners

in Canada keeping up-to-date with Continuing Forestry education?

Gilmore, D.W. and A.J. David - Current trends in management

practices for European larch in North America

Gordon, A. M., D. W. Larson, R. A. McBride, G. L. Lumis,

K. Rollins and S. Humphries - Learning about the forest using alternative curricula - the Guelph experience

Greene, D.F., D.D. Kneeshaw, C. Messier, V. Lieffers, D.

Cormier, R. Doucet, K.D. Coates, A. Groot, G. Grover, and

C. Calogeropoulos - Modelling silvicultural alternatives for

conifer regeneration in boreal mixedwood stands (aspen/white

spruce/balsam fir)

Groot, A. - See Greene, D.F.

Grover, G. - See Greene, D.F.

Hall, J. P. - Sustainable production of forest biomass for energy

Hansen, M.J. - See Franklin, S.E.

Hardy, Y. - The Canadian Forest Service: New directions for

science and technology

Harrison, P. - Attracting and keeping key talents

Harvey, B. - See Lefort, P.

Hedin, I. - See Paillé, G.

Heidersdorf, E. - See Paillé, G

Herring, L. - See Farnden, C.

Hollstedt, C. - Building extension into S \& T: Is this the missing

link?

Holmes, E., H. Lickers and B. Barkley - A critical assessment of ten years of on-the-ground sustainable forestry in eastern Ontario's settled landscape

Huang, S. - See Zhang, L.

Humphries, S. - See Gordon, A. M.

Hunt, L.M. - Exploring the availability of Ontario's non-industrial private forest lands for recreation and forestry activities

Innes, T. - Dare to share your information!

Johnson, F. - See Besseau, P.

Johnston, M. - See Lemprière, T.C.

Kabzems, R. - See Stone, D.M

Kaimowitz, D. - See Spilsbury, M.J.

Keenan, V. - See Ehnes, J.

Kimmins, H. - Future shock in forestry

Klinka, K. - See Nigh, G.D.

Kneeshaw, D.D. - See Greene, D.F.

Kneeshaw, D.D. - See Yamasaki, S.H.

Korber, D. - See Adamowicz, W.L.

Kozak, R. - See Saddler, J.

Kozak, R.A. - Internet readiness and e-Business adoption of

Canadian value-added wood producers

Kozak, R.A. - See Cohen, D.H

Kozak, R.A. - See Orban, J.L.

Krestov, P. V. - See Nigh, G.D

Kurz, W.A., M. Apps, E. Banfield and G. Stinson - Forest carbon accounting at the operational scale

LaPierre, L. - Canada's Model Forest Program

Larson, D.W. - See Gordon, A. M.

Lautenschlager, R.A. and T.P. Sullivan - Effects of herbicide

treatments on biotic components in regenerating northern forests

Lavigne, M.B. - See Franklin, S.E. 
Leadbitter, P., D. Euler and B. Naylor - A comparison of historical and current forest cover in selected areas of the Great Lakes-St. Lawrence Forest of central Ontario

Lefort, P., B. Harvey, J. Parton and G.K.M. Smith - Synthesizing

knowledge of the Claybelt to promote sustainable forest management 665

Lemprière, T.C., M. Johnston, A. Willcocks, B. Bogdanski,

D. Bisson, M. Apps and O. Bussler - Saskatchewan forest carbon

sequestration project

Lickers, H. - See Holmes, E.

Lieffers, V. - See Greene, D.F.

Lieffers, V.J., B.D. Pinno and K.J. Stadt - Light dynamics and

free-to-grow standards in aspen-dominated mixedwood forests

Loo, J. - See Betts, M.

Luckai, N. - Forestry education - Introduction

Luckai, N. - Undergraduate programs offered by the university

schools of forestry

Luckert, M.K. - Inquiries into the role of economics in Canadian

Forestry

Lumis, G.L. - See Gordon, A. M

MacKinnon, W.E. - See MacLean, D.A

MacLean, D.A., K.P. Beaton, K.B. Porter, W.E. MacKinnon and

M.G. Budd - Potential wood supply losses to spruce budworm in New

Brunswick estimated using the Spruce Budworm Decision Support

System

Macnab, B. - See Adamowicz, W.L.

Marchant, K. - Exotic forest pests - keeping them out

Martin, P.J., S. Bowne-Clayton and E. McWilliams - A results-

based system for regulating reforestation obligations

Masse, S. - Forest tenant farming as tested in Quebec: A socio-

economic evaluation

McBride, R.A. - See Gordon, A. M.

McGregor, D. - Indigenous knowledge in sustainable forest manage-

ment: Community-based approaches achieve greater success

McKee, D. - See Baker, J.A.

McLean, J. A. - Forestry graduate programs and research funding in

Canadian universities

McWilliams, E. - See Martin, P.J.

Messier, C. - See Greene, D.F.

Mitchell, S. J. and W.J. Beese - The retention system: reconciling

variable retention with the principles of silvicultural systems

Mohr, P.M. - Innovation and new product development: Key to

building shareholder value in forest products

Moores, L. and S. Dolter - Forest management planning in

Newfoundland and Labrador: The Western Newfoundland Model

Forest contribution

Moores, L. - Forest research in Newfoundland and Labrador: A new direction?

Munro, G. - FORCAST: A coalition for the advancement of

science and technology in the forest sector

Munson, A.D. - See Yamasaki, S.H.

Naylor, B. - See Leadbitter, P.

Naysmith, J.K. - International opportunities for undergraduate

forestry students at Canadian universities

Nigh, G.D. - See Cieszewski, C.J.

Nigh, G.D., P.V. Krestov, and K. Klinka - Height growth of black

spruce in British Columbia

Orban, J.L., R.A. Kozak, R.C. Sidle and S.J.B. Duff - Assessment

of relative environmental risk from logyard run-off in

British Columbia

Paillé, G., E. Heidersdorf and I. Hedin - FERIC: An innovation

driver for the Canadian forest sector

Parent, S. et J.-C. Ruel - Chronologie de la croissance chez des semis de sapin baumier (Abies balsamea (L.) Mill.) après une coupe à blanc

avec protection de la régéneration

Parkins, J. - See Beckley, T.

Parsons, C. - See Gauthier, J.

Parton, J. - See Lefort, P

Peng, C. - See Zhang, L.

Perron, J. - See Chouinard, O.

Pineau, J. - Technology transfer from an unlikely location

Pineau, M. - See Ruel, J.-C

Pinno, B.D. - See Lieffers, V.J.
Podlubny, D. - Canadian tech diploma courses over the years

Pollard, J. - See Erdle, T.

Porter, K.B. - See MacLean, D.A.

Rekmans, L. - Aboriginal people, science and innovation

Rollins, K. - See Gordon, A. M.

Rotherham, T. - Combining pride in ownership with management performance: A certification system for the woodlot sector

Ruel, J.-C. and M. Pineau - Windthrow as an important process for white spruce regeneration

Ruel, J.-C. - See Parent, S.

Saddler, J., R. Kozak and S. Watts - A university perspective on innovations in forestry science and technology

Saunders, K.C. and P.N. Duinker - Perceptions of barriers to

certification of government forestry in Newfoundland

Schaan, S. and Anderson, F. - Innovation in the forest sector

Sidle, R.C. - See Orban, J.L.

Smith, G.K.M. - See Lefort, P.

Smith, P. - Aboriginal Peoples and issues in forestry education in

Canada:Breaking new ground

Spilsbury, M.J. and D. Kaimowitz - Forestry research, innovation and impact in developing countries - from economic efficiency to

the broader public good

Stadt, K.J. - See Lieffers, V.J.

Stedman, R. - See Beckley, T.

Stenhouse, G. B. - See Franklin, S.E.

Stenhouse, G.B. - See Franklin, S.E.

Stephens, T. - Focus on the customer

Stinson, G. - See Kurz, W.A.

Stocks, B.J. - See Amiro, B.D

Stone, D.M. and R. Kabzems - Aspen development on similar

soils in Minnesota and British Columbia after compaction and forest floor removal

Su, J. - See Wang, G.G.

Sullivan, T.P. - See Lautenschlager, R.A.

Thomas, J. W. - Are there lessons for Canadian foresters lurking south of the border?

Veeman, T.S. - See Adamowicz, W.L.

Vyse, A. - See Benskin, H.J.

Wang, G.G. and Su, J. - Growth of black spruce seedlings planted in burned, logged, and undisturbed boreal mixedwood stands of southeastern Manitoba

ang, S. - Wicked pr

management over?

Watanabe, K.H. - See Gautam, K.H.

Watts, S. - See Saddler, J.

Weetman, G. - Intensive forest management: Its relationship to

$\mathrm{AAC}$ and $\mathrm{ACE}$

Wetzel, S. - See Duchesne, L.C.

Wiken, E. - See Cinq-Mars, J.

Willcocks, A. - See Lemprière, T.C.

Willick, M.L. - See Baker, J.A.

Wilson, M.A. - Alberta Research Council: Providing innovation from the forest to the finishing line

Wotton, B.M. - See Amiro, B.D

Wright, J.D. - No easy answers: Research and innovation for the

forestry sector

Wright, J.D. - Technology: The classic Canadian dilemma-

Short-term gain for long-term pain!

Wulder, M. A. - See Franklin, S.E.

Yamasaki, S.H., D.D. Kneeshaw, A.D. Munson and F. Dorion -

Bridging boundaries among disciplines and institutions for effective implementation of criteria and indicators

Zarnovican, R. - Impact du verglas de 1998 dans une érablière à

bouleau jaune en Estrie : Situation après trois ans

Zasada, J.C. - See Anderson, P.D.

Zasada, Z.A. - See Anderson, P.D.

Zeide, B. - Sharing data

Zhang, L., C. Peng, S. Huang and X. Zhou - Development and evolution of ecoregion-based jack pine height-diameter models for Ontario

Zhou, X. - See Zhang, L. 